\title{
PENGARUH PENERAPAN TERAPI SUPORTIF TERHADAP KEJADIAN POST PARTUM BLUES DI DESA BANJAR NEGORO KEC. WONOSOBO KAB. TANGGAMUS
}

\author{
Dainty Maternity ${ }^{1^{*}}$, Rilyani ${ }^{2}$, Maissy Hardianti ${ }^{3}$
}

${ }^{1,2}$ Dosen Universitas Malahayati

E-mail : denty.mf@gmail.com

${ }^{2}$ Mahasiswi keperawatan Universitas Malahayatl Bandar Lampung

E-mail : hardiantimaisy@gmail.com

\section{ABSTRACT: EFFECT OF IMPLEMENTATION OF SUPPORTIVE THERAPY ON THE EVENT OF POST PARTUM BLUES IN BANJAR NEGORO VILLAGE, KEC. WONOSOBO KAB. TANGGAMUS}

Introduction: According to the World Health Organization (WHO, 2017), in terms of gender, the female group recorded the highest incidence of mood disorders which was 5.1\%; compared to males 3.6\% (WHO, 2017). in terms of age, the incidence of mood disorders is high in the environment of late adulthood between 55 years to 74 years (7.5\% women: 5.5\% men) (WHO, 2017). Mental mood disorders occur in Southeast Asian countries 27\% compared to other overseas like Africa (9\%), Eastern Mediterranean (16\%), Europe (12\%), America (15\%) and the West Pacific (21\%) (WHO , 2017).

Objective: To find out the benefits of applying supportive therapy in post partum with the occurrence of baby blues in Banjar Negoro Village, Kec. Wonosobo Kab. Lampung Province Tanggamus in 2019.

Method: This type of research is quantitative. The research design of the Quasi Experimental method is one group pretest-posttest one group pretest-posttest approach. The population and sample were 20 people. Data analysis uses univariate and bivariate using t-tests.

Results: Post partum blues in post partum mothers before the application of supportive therapy in post partum mothers obtained an average EPDS score of 25.47 with the lowest EPD score of 18 and the highest EPD value of 30, and after the application of supportive therapy in post partum mothers obtained an average EPDS score of 14.29 with the lowest EPD score of 9, and the highest EPD score of 20, with a mean difference test of 12.100 . The results of statistical tests using dependent tests obtained $p$-values of $0,000(\alpha<0.05)$.

Conclusion: This means that there is an influence of the application of supportive therapy to the incidence of post partum blues in the village of Banjar Negoro Kec. Wonosobo Tanggamus Lampung Province in 2019. The results of this study can be used as an alternative treatment for clinics or places of care, if you find patients with post partum blues can use effective supportive therapy given to reduce the anxiety suffered.

Keywords: Supportive Therapy, Post Partum, Genesis Baby Blues 
INTISARI: PENGARUH PENERAPAN TERAPI SUPORTIF TERHADAP KEJADIAN POST PARTUM BLUES DI DESA BANJAR NEGORO KEC. WONOSOBO KAB. TANGGAMUS

Pendahuluan: Menurut World Health Organization (WHO, 2017), dari segi gender golongan wanita mencatatkan kadar kejadian gangguan mental kemurungan paling tinggi yaitu 5.1\%; berbanding lelaki 3.6\% (WHO, 2017). dilihat segi umur, kejadian gangguan mental kemurungan adalah tinggi dalam lingkungan umur dewasa akhir di antara 55 tahun hingga 74 tahun $(7.5 \%$ wanita : $5.5 \%$ lelaki) (WHO, 2017). Kejadian gangguan mental kemurungan terjadi di negara Asia Tenggara 27\% berbanding lain-lain rantau seperti Afrika (9\%), Timur Mediterranean (16\%), Eropa (12\%), Amerika (15\%) dan Barat Pasifik (21\%) (WHO, 2017).

Tujuan: Diketahui manfaat penerapan terapi suportif pada post partum dengan kejadian baby blues di Desa Banjar Negoro Kec. Wonosobo Kab. Tanggamus Provinsi Lampung Tahun 2019.

Metode: Jenis penelitian ini adalah Kuantitatif. Desain penelitian metode Quasi Eksperimental pendekatan one group pretes-postes one group pretes-postes. Populasi dan sampel sebanyak 20 orang. Analisa data mengguanakan univariat dan bivariate dengan $t$-tes.

Hasil : Post partum blues pada ibu post partum sebelum penerapan terapi suportif pada ibu post partum didapat nilai rata-rata skor EPDS sebesar 25,47 dengan skor nilai EPD terendah 18 dan nilai nilai EPD tertinggi 30, dan sesudah penerapan terapi suportif pada ibu post partum didapat nilai rata-rata skor EPDS sebesar 14,29 dengan skor nilai EPD terendah 9, dan skor nilai EPD tertinggi 20, dengan nilai uji beda mean 12,100. Hasil uji statistik menggunakan tes-dependen didapat nilai $p$-value $0.000(a<0.05)$.

Kesimpulan : Artinya terdapat pengaruh penerapan terapi suportif terhadap kejadian post partum blues di Desa Banjar Negoro Kec. Wonosobo Tanggamus Provinsi Lampung Tahun 2019. Hasil penelitian ini dapat digunakan sebagai alternatif pengobatan bagi klinik atau tempat perawatan, jika menemukan pasien dengan post partum blues dapat menggunakan terapi suportif yang efektif diberikan untuk mengurangi cemas yang diderita.

Kata Kunci: Terapi Suportif, Post Partum, Kejadian Baby Blues

\section{PENDAHULUAN}

Gejala depresi postpartum merupakan salah satu dari kategori gangguan mental yang tercatan sebagai prevalens paling tinggi di seluruh negara di dunia. Pada peringkat global, World Health Organization (WHO) mengklasifikasikan kemurungan sebagai gangguan mental paling tinggi yang berlaku dan sedang melanda di kebanyakan negara di dunia, salah satunya adalah negara

maju ataupun negara
berkembang (WHO, 2017).
Hasil laporan World
Health Organization (WHO,
2017) terhadap tinjauan
kesehatan global pada tahun
2016 mendapati pada peringkat
global jumlah keseluruhan
individu yang menghidapi
gangguan mental kemurungan di
dunia sebanyak 322 juta orang.
Hampir separuh dari jumlah
tersebut terdiri dari kalangan
baik negara Asia Tenggara (27\%)


dan Barat Pasifik (21\%) (WHO, 2017).

Menurut World Health Organization (WHO, 2017), dari segi gender golongan wanita mencatatkan kadar kejadian gangguan mental kemurungan paling tinggi yaitu $5.1 \%$; berbanding lelaki $3.6 \%$ (WHO, 2017). dilihat segi umur, kejadian gangguan mental kemurungan adalah tinggi dalam lingkungan umur dewasa akhir di antara 55 tahun hingga 74 tahun (7.5 \% wanita : $5.5 \%$ lelaki) (WHO, 2017). Kejadian gangguan mental kemurungan terjadi di negara Asia Tenggara $27 \%$ berbanding lain-lain rantau seperti Afrika (9\%), Timur Mediterranean (16\%), Eropa (12\%), Amerika (15\%) dan Barat Pasifik (21\%) (WHO, 2017).

Post Partum Blues sendiri sudah dikenal sejak lama. Savage pada tahun 1875 telah menulis referensi bahwan post partum blues suatu keadaan disforia ringan pasca persalinan, atau sindrom gangguan afek ringan yang sering tampak dalam minggu pertama setelah persalinan berlangsung, hal ini merupakan masalah yang menyulitkan dan tidak menyenangkan serta dapat membuat perasaan tidak nyaman bagi yang mengalaminya, bahkan kadangkadang gangguan ini dapat berkembang menjadi keadaan yang lebih berat yaitu depresi dan Psikosis Post Partum (Yuke, 2015). Angka kejadian beresiko pada usia $<20-\geq 30$ tahun, sedangkan usia yang tidak beresiko sekitar $21-34$ tahun dan paritas pada primipara dan multipara, pengalaman dalam proses kehamilan dan persalinan serta dukungan psikososial antara lain, status perkawinan, kehamilan yang tidak diinginkan, riwayat gangguan jiwa sebelumnya (Yuke, 2015). Dampak dari kejadian Postpartum blues dapat mempengarungi banyak hal, seperti psikis ibu, keadaan diri dan sekitar termasuk keamanan bayi yang dilahirkan. Tidak banyak kasus yang terjadi, seperti pembunuhan dan penganiayaan bayi. Keadaan yang menyerang mood serta kejiwaan ibu ini memerlukan penanganan yang khusus. Selain pengobatan di Rumah Sakit dan dukungan keluarga, terapi lain sangat dianjurkan bagi ibu pasca bersalin, seperti terapi musik, yang bertujuan memberikan sensasi rileks bagi ibu (Hikmah, 2006). Seperti kasus kematian bayi calista yang berusia 15 bulan, meninggal usai dianiaya oleh ibu kandungnya, yang diduga oleh keadaan ekonomi dan kesiapan mental menjadi orangtua. Faktor ekonomi menyebabkan meningkatnya kesejahteraan atau malah sebaliknya, yang akan berdampak pada psikologi seseorang, yang tidak mampu menerima keadaan dan kekurangan ekonomi.

(Terapi Suportif) secara kelompok adalah terapi supportif yang diberikan pada sekelompok anggota dengan karakteristik dan permasalahan yang relatif homogen. Berdasarkan penjelasan di atas, dapat dinyatakan bahwa terapi suportif merupakan suatu terapi yang bersifat memberikan dukungan dan semangat kepada pesertanya melalui kerjasama antar anggota. Di dalam pelaksanaan Terapi Suportif ada aturan yang membedakannya dari psikoterapi kelompok lainnya, yakni adanya 
'saran' yang mendorong para anggota yang mengikutinya untuk melakukan interaksi di luar sesi (Yalom, 1995; Yuke, 2015). Berdasarkan data dinas kesehatan Kotaagung didapat 3 kecamatan dengan angka pernikahan usia muda tertinggi, yaitu Kec. Wonosobo dengan jumalah 159 orang perinikahan dini, Kec. Talang Padang dengan angka pernikahan usia muda sebanyak 128 orang, dan Kec. Gisting dengan angka pernikahan usia dini 90 orang, pernikahan dini dapat memberikan dampak pada emosi ibu pasca melahirkan, seperti kesiapan memiliki anak, ekonomi, serta kecemasan yang dirasakan ibu ketika mengurus anak (Dinkes Kotaagung, 2018).

Di Desa Banjar Negoro

Kec. Wonosobo Tanggamus Provinsi Lampung terapi suportif belum pernah diberikan pada ibu hamil trimester III untuk mengurangi perasaan cemas dan takut setelah bersalin yang dirasa, berdasarkan presurvey yang telah dilakukan didapat 29 ibu hamil trimester III 9 orang (31.03\%) menyatakan tidak keberatan dengan proses kehamilannya, sedangkan 20 orang ibu (68.97\%) merasa tertekan dan cemas ketika akan menghadapi persalinan dan kelanjutan untuk mengurus anak.

Berdasarkan latar belakang diatas peneliti tertarik melakukan penelitian dengan judul "Pengaruh Penerapan Terapi Suportif Terhadap Kejadian Post Partum Blues Di Desa Banjar Negoro Kec. Wonosobo Tanggamus Provinsi Lampung Tahun 2019"

\section{METODE PENELITIAN}

Jenis penelitian ini merupakan jenis penelitian kuantitatif. Jenis penelitian kuantitatif adalah penelitian dengan memperoleh data yang berbentuk angka atau kualitatif yang diangkakan (Notoadmodjo, 2018). Rancangan dalam penelitian ini menggunakan desain Quasi Eksperimental dengan pendekatan one group pretest - posttest design. Populasi dalam penelitian ini adalah seluruh ibu nifas di Desa Banjar Negoro Kec. Wonosobo Tanggamus Provinsi Lampung pada bulan januari-februari 2019 sebanyak 45 orang.

HASIL

Analisa Univariat

1. Sebelum Intervensi

Rerata Post Partum Blues Pada Ibu Post Partum Sebelum Penerapan Terapi Suportif Di Desa Banjar Negoro Kec. Wonosobo Tanggamus Provinsi Lampung Tahun 2019

\begin{tabular}{cccccc}
\hline Post Partum Blues & N & Mean & SD & SE & Min-Max \\
\hline Sebelum & 20 & 25,90 & 3,177 & 0,710 & $18-30$ \\
\hline
\end{tabular}

Dari tabel diatas dapat diketahui bahwa rerata post partum blues pada ibu post partum sebelum penerapan terapi suportif di Desa Banjar Negoro Kec. Wonosobo
Tanggamus Provinsi Lampung Tahun 2019 terhadap 20 orang ibu post partum, dengan mean 25,90 standar deviasi 3,177 standar eror 
0,710 dan nilai min-max 18 -

30 .

2. Setelah Intervensi

Rerata Post Partum Blues Pada Ibu Post Partum Sesudah Penerapan Terapi Suportif Di Desa Banjar Negoro Kec. Wonosobo Tanggamus Provinsi Lampung Tahun 2019

\begin{tabular}{cccccc}
\hline Post Partum Blues & N & Mean & SD & SE & Min-Max \\
\hline Sesudah & 20 & 13,80 & 4,034 & 0,902 & $9-20$ \\
\hline
\end{tabular}

Dari tabel diatas dapat diketahui bahwa rerata post partum blues pada ibu post partum sesudah penerapan terapi suportif di Desa Banjar Negoro Kec. Wonosobo
Tanggamus Provinsi Lampung Tahun 2019 terhadap 20 orang ibu post partum, dengan mean 13,80 standar deviasi 4,034 standar eror 0,902 dan nilai min-max 9-20

Analisis Bivariat

Pengaruh Penerapan Terapi Suportif Terhadap Kejadian Post Partum Blues Di Desa Banjar Negoro Kec. Wonosobo Tanggamus Provinsi Lampung Tahun 2019

\begin{tabular}{cccccc}
\hline Variabel & N & Mean & SD & SE & $\begin{array}{c}\text { P- } \\
\text { Value }\end{array}$ \\
\cline { 1 - 5 } Sebelum & 20 & 25,90 & 3,177 & 0,710 & \\
\cline { 1 - 4 } Sesudah & 20 & 13,80 & 4,034 & 0,902 & 0.000 \\
\cline { 1 - 4 } Selisih & 12,100 & 4,291 & 0,959 & \\
\hline
\end{tabular}

Dari tabel 4.5 terlihat bahwa perbedaan hasil pengukuran terhadap 20 responden untuk melihat rerata post partum blues pada ibu post partum sebelum penerapan terapi suportif di Desa Banjar Negoro Kec. Wonosobo Tanggamus Provinsi Lampung Tahun 2019 dengan mean 25,90 standar deviasi 3,177 standar eror 0,710 rerata post partum blues pada ibu post partum sesudah penerapan terapi suportif dengan mean 13,80

\section{PEMBAHASAN}

Analisa Univariat

1. Rerata Post Partum Blues Pada Ibu Post Partum Sebelum Penerapan Terapi Suportif Di Desa Banjar Negoro Kec. Wonosobo Tanggamus Provinsi Lampung Tahun 2019 standar deviasi 4,034 standar eror 0,902 , dengan nilai uji beda mean 12,100 , standar deviasi 4,291 standar eror 0,959.

Hasil uji statistik menggunakan tes-dependen didapat nilai $p$-value $0.000(\alpha<0.05)$ yang artinya terdapat pengaruh penerapan terapi suportif terhadap kejadian post partum blues di Desa Banjar Negoro Kec. Wonosobo Tanggamus Provinsi Lampung Tahun 2019.

Post partum blues pada ibu post partum sebelum penerapan terapi suportif pada ibu post partum didapat nilai rata-rata skor EPDS sebesar 25,90 dengan skor nilai EPD terendah 18 dan nilai nilai EPD tertinggi 30 
Sejalan dengan teori Maritalia (2012) postpartum blues merupakan perasaan sedih yang dialami oleh seorang ibu berkaitan dengan bayinya. Biasanya muncul sekitar 2 hari sampai 2 minggu sejak bayinya lahir. Keadaan ini disebabkan oleh perubahan perasaan yang dialami ibu saat hamil sehingga sulitt menerima kehadiran bayinya. Pertubahan perasaan ini merupakan respon alami terhadap lelah yang dirasakan. Selain itu juga karena perubahan fisik dan emosional selama beberapa bulan kehamilan. Perubahan hormone yang sangat cepat antara kehamilan dan setelah proses persalinan sangat berpengaruh dalam hal bagaimana ibu bereaksi terhadap situasi yang berbeda.

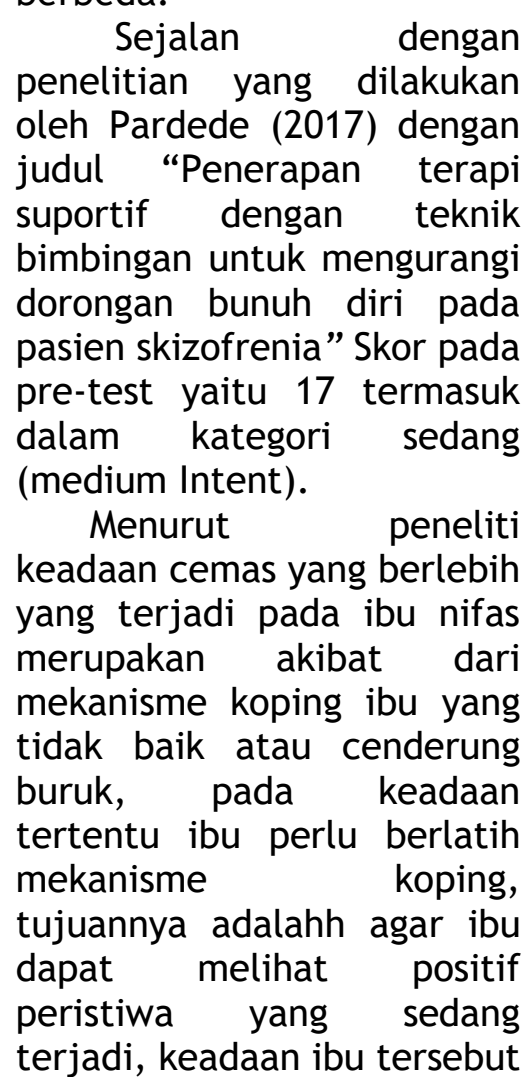

juga dapat terjadi akibat kelelahan, beban fikiran yang berat seperti kebutuhan ekonomi setelah anak lahir, tidak dapat mengasuh dan merawat bayi dengan baik, sehingga timbullah sikap pesimis yang berujung pada kecemasan yang berlebih.

2. Rerata Post Partum Blues Pada Ibu Post Partum Sesudah Penerapan Terapi Suportif Di Desa Banjar Negoro Kec. Wonosobo Tanggamus Provinsi Lampung Tahun 2019

Post partum blues pada ibu post partum sesudah penerapan terapi suportif pada ibu post partum didapat nilai rata-rata skor EPDS sebesar 13,80 dengan skor nilai EPD terendah 9, dan skor nilai EPD tertinggi 20.

Sejalan dengan teori yang dikemukakan oleh Chris (2014) Psikoterpai suportif merupakan modalitas terapi berupa intervensi psikoanalitik yang bertujuan untuk memperkuat kemampuan pasien dalam menghadapi masalaha yang dimilikinya. Aplikasi psikoterapi suportif terutama dititik beratkan pada beberapa aktivitas utama yaitu mendengar aktiv dan menunjukan ekspresi yang tepat ; memebantu meningkatkan hargadiri individu dan kegembiraan; serta menyakinkan bahwa ada harapan disetiap masalah.

Sejalan dengan penelitian yang dilakukan oleh Pardede (2017) dengan judul "Penerapan terapi suportif dengan teknik bimbingan untuk mengurangi dorongan 
bunuh diri pada pasien skizofrenia" skor post-test yaitu 5 termasuk kedalam kategori rendah (low intent).

Menurut peneliti keadaan cemas yang berlebih pada ibu dapat diatasi dengan memberikan serangkaian terapi serta dukungan positif dari keluarga terdekat seperti suami, ibu atau anggota keluarga yang lain, yang telah lebih berpengalaman dalam merawat bayi, memberikan terapi, seperti terapi murotal tujuannya adalah memberikan rasa nyaman bagi ibu, sehingga ibu merasa lebih tenang dan aman, dan diharapkan ibu dapat memenuhi kualitas tidurnya, bersamaan dengan diberikannya terapi murotal tersebut, sehingga ibu lebih merasa percaya diri dan memiliki semnagat positif dalam merawat bayinya, ibu juga lebih dekat dengan Sang Pencipta.

\section{Analisa Bivariat}

1. Pengaruh Penerapan Terapi Suportif Terhadap Kejadian Post Partum Blues Di Desa Banjar Negoro Kec. Wonosobo Tanggamus Provinsi Lampung Tahun 2019

Post partum blues pada ibu post partum sebelum penerapan terapi suportif pada ibu post partum didapat nilai rata-rata skor EPDS sebesar 25,90 dengan skor nilai EPD terendah 18 dan nilai nilai EPD tertinggi 30, dan sesudah penerapan terapi suportif pada ibu post partum didapat nilai ratarata skor EPDS sebesar 13,80 dengan skor nilai EPD terendah 9, dan skor nilai EPD tertinggi 20, dengan nilai uji beda mean 12,100, standar deviasi 4,291 standar eror 0,959 .

Hasil uji statistik menggunakan tes-dependen didapat nilai $p$-value 0.000 $(\alpha<0.05)$ yang artinya terdapat pengaruh penerapan terapi suportif terhadap kejadian post partum blues di Desa Banjar Negoro Kec. Wonosobo Tanggamus Provinsi Lampung Tahun 2019.

Sejalan dengan teori Srihartono (2011) Terapi suportif merupakan psikoterapi yang ditujukan untuk klien baik secara individu maupun secara kelompok yang ingin mengevaluasi diri, melihat kembali cara menjalani hidup, mengeksplorasi pilihan-pilihan yang tersedia bagi individu maupun kelompok dan bertanya kepada diri sendiri hal yang diingini di masa depan

Sejalan dengan penelitian yang dilakukan oleh Sri (2018). Penurunan Postpartum Blues Dan Ansietas Melalui Terapi Thought Stopping Dan Terapi Suportif Pada Ibu Postpartum Dengan Bayi Prematur. Hasil penelitian menunjukkan ada penurunan postpartum blues dan ansietas secara bermakna $(p$-value $=0,000)$ pada kelompok yang mendapat tindakan keperawatan Ners, terapi thought stopping dan terapi suportif, dan lebih besar penurunan secara bermakna 
$\begin{array}{lr}\begin{array}{l}\text { dibandingkan } \\ \text { kelompok yang }\end{array} & \begin{array}{r}\text { dengan } \\ \text { hanya } \\ \text { mendapat }\end{array} \\ \text { tindakan } \\ \begin{array}{c}\text { keperawatan Ners. } \\ \text { Menurut }\end{array} & \begin{array}{c}\text { peneliti, } \\ \text { kecemasan wajar }\end{array} \text { terjadi }\end{array}$ pada ibu yang memiliki bayi atau setelah bersalin, karena beberapa faktor, akan tetapi tingkat kecemasan pada setiap responden berbedabeda tergantung bagaimana cara mengatasi persoalan yang terjadi. Ibu yang memiliki keyakinan kuat terhadap rasa tenang dengan melakukan ibadah memiliki tingkat kecemasan yang kurang dari seseorang yang tidak menggunakan kekuatan spiritual untuk membantu dirinya menghadapi kecemasan, apabila mekanisme tersebut dilakukan dengan efektif, stressor tidak lagi menimbulkan tekanan secara psikis, atau rasa sakit, melainkan berubah menjadi stimulant yang memacu keadaan kondisi fisik dan mental yang baik, mekanisme koping menunjuk pada baik mental maupun perilaku untuk menguasai, mentoleransi, dan meminimalisir suatu keadaan yang menekan, mekanisme tersebut merupakan suatu proses untuk menangani kecemasan yang sedang dialami dengan cara berbagi cerita atau perasaan dengan lingkungan sekitar, seperti suami, orangtua, atau teman. Pada penelitian ada beberapa faktor yang mempengaruhi penurunan kecemasan pada ibu post partum yaitu usia tidak beresiko dengan nilai selisih rata-rata sebelum dan sesudah perlakuan sebesar 10,82 usia kehamilan 37 minggu dengan nilai selisih rata-rata sebelum dan sesudah perlakuan sebesar 10,28 selanjutnya pendidikan tinggi (D3) dengan nilai selisih rata-rata sebelum dan sesudah perlakuan sebesar 10,34 . Usia saat hamil sangat mempengaruhi kesiapan serta emosional ibu yang akan menghadapai persalinan, ibu dengan usia tidak beresiko lebih siap baik fisik maupun mental, sama halnya dengan usia kehamilan saat bersalin, ideal usia kehamilan saat bersalin adalah 37-40 minggu, sedangkan pendidikan yang tinggi mempengaruhi seseorang dalam menerima dan memutuskan suatu masalah, seperti kesiapan memiliki bayi, ataupun merawat bayi.

Pada pendidikan tinggi, akan berpengaruh pada keadaan sosia; dan ekonomi seseorang, ekonomi yang mendukung, baik dari segi makanan, minuman serta pengobatan dapat berdampak pada kesejahteraan ibu, sehingga ibu merasa lebih siap dan mampu untuk merawat anak pasca bersalin.

\section{KESIMPULAN DAN SARAN \\ Kesimpulan}

Berdasarkan penelitian dengan judul "Pengaruh Penerapan Terapi Suportif Terhadap Kejadian Post Partum Blues Di Desa Banjar Negoro Kec. Wonosobo Tanggamus Provinsi Lampung Tahun 2019" maka dapat disimpulkan sebagai berikut : 
1. Rerata post partum blues pada ibu post partum sebelum penerapan terapi suportif dengan mean 25,90 standar deviasi 3,177 standar eror 0,710 dan nilai min-max 18-30.

2. Rerata post partum blues pada ibu post partum sesudah penerapan terapi suportif dengan mean 13,80 standar deviasi 4,034 standar eror 0,902 dan nilai min-max 9-20.

3. Hasil uji statistik menggunakan tes-dependen didapat nilai $p$-value 0.000 $(\alpha<0.05)$ yang artinya terdapat pengaruh penerapan terapi suportif terhadap kejadian post partum blues di Desa Banjar Negoro Kec. Wonosobo Tanggamus Provinsi Lampung Tahun 2019.

\section{DAFTAR PUSTAKA}

FAo, I. F. A. D., \& UNICEF. (2017). WFP, WHO (2017) The state of food security and nutrition in the world 2017. Building resilience for peace and food security. FAO, Rome. URL: http: / /www. fao. org/3/ai7695e. pdf (Accessed 16 May 2018).

Kirana, Y. (2015). Hubungan tingkat kecemasan post partum dengan kejadian post partum blues di rumah sakit dustira cimahi. Jurnal Keperawatan BSI, 3(1).

Laela, S., Keliat, B. A., \& Mustikasari, M. (2018). Penurunan Postpartum Blues Dan Ansietas Melalui Terapi Thought Stopping dan Terapi

\section{Saran \\ Bagi Desa Banjar Negoro Kec. Wonosobo Tanggamus \\ Hasil penelitian ini dapat digunakan sebagai alternatif pengobatan bagi klinik atau tempat perawatan, jika menemukan pasien dengan post partum blues dapat menggunakan terapi suportif yang efektif diberikan untuk mengurangi cemas yang diderita. \\ Peneliti Selanjutnya \\ Hasil penelitian ini diharapkan dapat menjadi acuan bagi peneliti selanjutnya untuk melakukan penelitian terkait lainnya, dengan terapi suportif, dengan variabel terkaitnya yaitu untuk menurunkan cemas dan depresi pasca bersalin.}

Suportif Pada Ibu Post Partum Dengan Bayi Prematur. Care: Jurnal Ilmiah Ilmu Kesehatan, 6(1), 26-35.

Maritalia, D. (2012). Asuhan kebidanan nifas dan menyusui. Yogyakarta: Pustaka Pelajar.

Pardede, A., Adfa, M., Kusnanda, A. J., Ninomiya, M., \& Koketsu, M. (2017). Flavonoid rutinosides from Cinnamomum parthenoxylon leaves and their hepatoprotective and antioxidant activity. Medicinal Chemistry Research, 26(9), 2074-2079.

Tanto, C., Liwang, F., Hanifati, S., \& Pradipta, E. A. (2014). Kapita selekta kedokteran. Jakarta: Media Aesculapius, 329-3 